\title{
Educating for Character in Work Readiness Through Vocational Higher Education in the Digital Era
}

\author{
Kusnar Budi* \\ Finance and Banking Administration Study Program, \\ Vocational Education Program, Universitas Indonesia \\ Depok, Indonesia \\ *E-mail: budikusnar@yahoo.co.id
}

\begin{abstract}
This paper discusses the implementation of a new curriculum in the Financial and Banking Administration Study Program at the Universitas Indonesia's Vocational Education Program, and more specifically, aspects of educating students in the area of character for work readiness in this digital era. It is a strategy aimed at producing graduates who are ready to compete within a challenging labor market. This study aims to explain the process and content of educating for character in the learning activities in the study program. The data were derived from primary and secondary sources. Data and information from the primary sources were collected through interviews and observation. Interviews were conducted with lecturers of subjects in the study program, as well as with students who were involved in the learning activities. The collected data were analyzed using a content analysis method. Results of the study describe three stages in the implementation, including the preparation stage, implementation stage, and evaluation or reflection stage. The object of the core content of educating for character is to educate and train students regarding respect and responsibility values. This can be elaborated into four major skills that should be developed, namely, personal skills, interpersonal skills, group skills, and information technology skills. Development of the content of educating for character in work readiness was based on the curriculum of vocational education that relates to society and industry as well as to the digital era. It involves collaboratively integrating activities in the classroom with activities of serving the community, as well as the internship program. After completing the course in educating for character for work readiness, the graduates of the Vocational Education Program of Universitas Indonesia have a strong personal character, practical experience of work skills, and a positive attitude, as well as practical knowledge.
\end{abstract}

Keywords: curriculum, educating for character, work skills, digital era

\section{Introduction}

Today the world of education faces challenges of the era that change from time to time. This is related to the rapid development of technology, specifically information technology, which also influences the goals and targets, as well as the output and outcomes, of education provision. It is evident that information technology dominates all aspects of people's lives in this 21 st century, so this is often referred to as the century of "knowledge society." The presence of information technology, together with electronic information systems, produces the integrated global economy (Crawford, 1991, p. 6). Therefore, economy and trade between countries form an integrated system, and the boundaries between countries are weakened by the presence of global trade agreements or blocks. Minister of State-Owned Enterprises of the Republic of Indonesia, Rini Soemarno (2018), mentions several examples of the agreements that the country is involved in, such as the ASEAN Free Trade Area (AFTA), since 2013, the China ASEAN Free Trade Area (C-AFTA) since 2010, the India ASEAN Free Trade Area (I-AFTA) since 2011, the ASEAN Economic Community since 2015, and the World Trade Organizations in 2020. In relation to this, the productivity of the people in the country faces global competition, as well as the rapid technological developments in the digital era and the era of industrial revolution 4.0, which can be an opportunity as well as a challenge for the nation. These conditions cause the traffic of capital, technology, and labor to be more dynamic and move more freely across the world. This era is often referred to as the digital era, where the working methods of producing goods and services utilize various applications of information and robotic technologies. This presents a challenge for educational implementers in this case study of vocational higher education in preparing human resources in the form of graduates who are ready to work in these environmental conditions. The digital era is also called the information age, wherein most 
people use information technology and information systems when using a personal computer and thus have the ability to process and transfer information freely and quickly. Shepherd (2004) explains that "the digital era is characterized by technology which increases the speed and breadth of knowledge turnover within the economy and society. The digital era can be seen as the development of an evolutionary system in which knowledge turnover is not only very high, but also increasingly out of the control of humans, making it a time in which our lives become more difficult to manage." This era requires a specific approach in the ground to manage.

Currently, the reality is that the quality of human resources in Indonesia is still low. This is demonstrated by the various problems in society, especially those related to the quality of Indonesian human resources, which are not competitive. Based on the Human Development Report of 2016, published by the United Nations Development Program (UNDP), Indonesia's Human Development Index (HDI) rankings in 2015 fall in the low category, being 113th out of 188 countries, which is a decline from the 110th position of 2014. Although it is true that from 1990 to 2015 the HDI in Indonesia experienced an increase from 0.528 to 0.689 , or showed an increase of $30.5 \%$ (UNDP Report, 2016), the quality of Indonesian human resources needs to be enhanced so that it can be more competitive in the world of work. If we compare the position of Indonesia with other countries: Thailand (87); Malaysia (59); Brunei Darussalam (30); South Korea (18); and Singapore (5), we can see that the quality of human development in the country is still lagging behind.

The Government of the Republic of Indonesia ruled that higher education be classified into three main types, namely, academic, vocational, and professional education. Academic education comprises higher education in the graduate and postgraduate programs, which are directed toward mastering and developing in a certain branch of science and technology. Vocational education includes higher education in a diploma program that prepares students to acquire a certain type of applied skills which can be developed up to the level of a bachelor's program, whereas professional education involves higher education programs after a bachelor's degree, preparing students to be ready for jobs with specific expertise requirements (Law number 12/ year 2012 on Higher Education).

Vocational education is an educational institution that plays a major role in producing human resources with applied skills, ready to begin working directly after graduating, or to enter the working world. In response to the demand for skilled human resources in the labor market, the government is continuously revitalizing vocational education, with the main goal of improving the absorption of graduates into the working world. The government's policies on revitalization of vocational education have also been motivated by the fact that the number of vocational students in Indonesia is lower than in other countries in the world. Efforts to revitalize vocational education will be focused on preparing or designing a new curriculum which is adapted to the requirements of the industries, and on improving facilities such as laboratories and other infrastructures, as well as the capacity of lecturers (Direktorat Kelembagaan Iptek \& Dikti, 2016).

The focus of revitalization in vocational education relates to increasing the number of graduates who have work competencies that match the industries' requirements. This is the primary target of vocational education: to create graduates that are ready to work. Therefore, in the learning process, students or participants in education will receive more practice activities in laboratories and/or in the industries, rather than studying theories in the classroom. Indicators for the work readiness of graduates comprise their degree of skills or work competencies which include their character or attitude, such as discipline, honesty, responsibility, intelligence, carefulness, helpfulness, and teamwork abilities (kelembagaan.ristekdikti.go.id, 2017). A study conducted by Widarto (n.d) explains that in the working world, the quality of employees' performance is mostly influenced by their attitude and character (28.33\%), physical condition (26.33\%), knowledge (23\%), and skills $(22.3 \%)$. Attitude and character thus constitute the biggest component in the assessment of the employees' performance quality. This indicates that the main critical indicators for the quality of human resources to enter the labor market competition are attitude and character. Based on the above background, this paper discusses educating for character in work readiness as a means to produce graduates from vocational programs who are ready to compete within the labor market.

\section{Literature Review}

\subsection{Educating for Character: Elements and Values}

In education for character for work readiness, there are three basic elements, namely, attitude, skills, and knowledge (ASK) that are essential for the performance of efficient and effective work in a certain job, or in other words, for work competence (Wibawa, 2017). Vocational education and training institutions have to provide the three essential elements in their curriculum, so that students will be well prepared and will have mastered work readiness. The first element, attitude, has two fundamental values that need to be taught: respect and responsibility. These values constitute the core of a universal, public morality. They have objective, demonstrable worth in that they promote the good of the individual and the good of the whole community. These two values, respect and responsibility, are necessary for healthy personal development, caring 
interpersonal relationships, a humane and democratic society, and a just, peaceful world (Lickona, 1991, pp. 4345).

Furthermore, Lickona (1991) explains that respect means showing regard for the worth of someone or something, and takes three major forms: respect for oneself, respect for other people, and respect for all forms of life and the environments that sustain them. Respect for self requires us to treat our own life and person as having inherent value. That is why it is wrong, for example, to engage in self-destructive behavior such as drug or alcohol abuse. Respect for others requires us to treat all other human beings, even those we dislike, as having dignity and rights equal to our own. Moreover, respect for property, for example, comes from understanding that property is an extension of a person or a community of persons, while respect for authority comes from understanding of the legitimate authority figures entrusted with the care of others.

Responsibility is, in fact, an extension of respect. If we respect other people, we value them. If we value them, we feel a measure of responsibility for their welfare. Responsibility basically means "ability to respond." It means orienting toward others, paying attention to them, and actively responding to their needs. It emphasizes our positive obligation to care for each other.

Further, there are other moral values such as honesty, fairness, tolerance, prudence, self-discipline, helpfulness, compassion, cooperation, and courage. Honesty, or dealing with other people by not deceiving them, cheating them, or stealing from them, is one way of respecting them. Fairness means treating people impartially, and not playing favorites. Tolerance is an expression of respect, and constitutes a fair objective attitude toward those whose ideas, race, or creed are different from our own. Another value which is very important in the finance and banking business is prudence, which warns us not to put ourselves in physical or moral danger, or, in other words, means "avoiding the occasion of sin." In a similar way, values such as helpfulness, compassion, cooperation, and courage help us in carrying out the broad ethic of responsibility (Lickona, 1991, pp. 45-46).

The second essential element is skills, which as Whetten and Cameron (1995) explain, include three major areas: personal and interpersonal skills, group skills, and specific communication skills. In the context of the digital era, specific communication skills relate to information technology skills.

Personal skills include developing self-awareness, managing stress, and solving problems creatively. Developing self-awareness relates to priority of values, maturity, attitude toward life, cognitive style, and interpersonal orientation. Managing stress includes time management, stress management, and social adjustment. Solving problems creatively involves understanding a problem and its constraints and creating opportunities to find a way of solving it.

Interpersonal skills relate to the ability to communicate with others supportively, to influence and gain power or support from others, to motivate others, and to manage conflicts.

Group skills involve the ability to work with other people in a team or teams, for example, sharing ideas to gain mutual understanding, as well as the ability to ask others for support and cooperation in achieving the common organizational objectives or goals efficiently and effectively.

Information technology skills include the ability to understand and operate digital technologies such as computer programs and software used in working activities.

The third element, knowledge, is about understanding of the world of work in a specific area, for example, in the finance and banking industry. In relation to educating and creating good character, there are three components to this element, namely, moral knowing, moral feeling (the emotional side of character), and moral action (the outcome of the two other parts) as shown in Figure 1. Therefore, all knowledge should be categorized into these three components before it is transformed into an action (Lickona, 1991, p. 53).

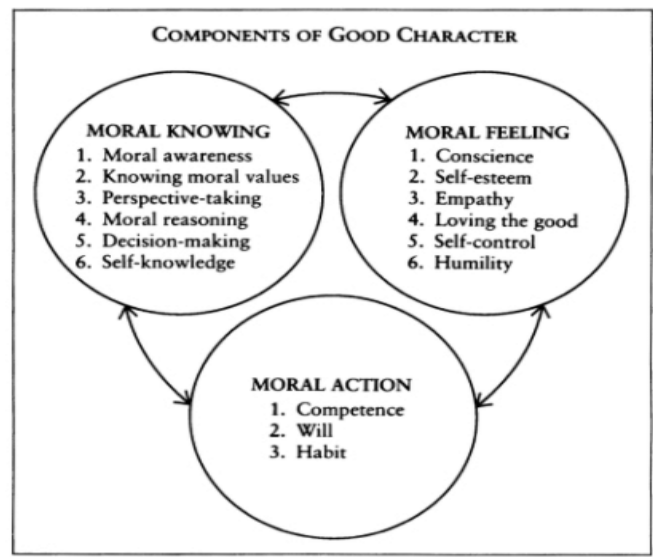

Figure 1. Components of Good Character. Reprinted from Educating for character: How our schools can teach respect and responsibility (p. 53) by T. Lickona (1991), New York: Bantam Books 
Lickona (1991, p. 63) explains that character does not function in a vacuum; it functions in a social environment. Often the environment suppresses moral concern. Sometimes it is the case that many or even most people do not do the "moral thing." An example is the response of people who find someone's wallet or pocket book in a street. People's response will vary, depending on the environment and the background of the people who find it.

Character is also influenced by the dynamic technologies environment. Currently, we live in the information age that is starting to reach another stage known as "the shift age", a time when much of humanity will change the way they live, think, or interact with each other, and what they do in their work (Houle, 2012, p. 10), and this is what is often called the digital era. Shepherd (2004) explains that "the digital era is characterized by technology which increases the speed and breadth of knowledge turnover within the economy and society. The digital era can be seen as the development of an evolutionary system in which knowledge turnover is not only very high, but also increasingly out of the control of humans, making it a time in which our lives become more difficult to manage." This relates to what Lickona states above, that character, in fact, functions in a dynamic social environment, and there is thus an urgent need that educating for character be developed or included in the academic curriculum.

Educating for character as part of a school or study program strategy can be done within the classroom or in laboratories, and beyond the classroom, such as in industries where students follow internship programs supervised by the officials of the company or institution. It can also be done in communities where students undertake community-service-related subjects designed for this purpose and supervised by their lecturers, trainers, or supervisors. In relation to this, the roles of lecturers and trainers becomes very important in training students to become knowing (having knowledge), doing (exercising skills), and loving (making a habit) of the three elements (ASK) which are fundamentally based on two major values: respect and responsibility. Figure 2 shows a comprehensive approach to values and character education.

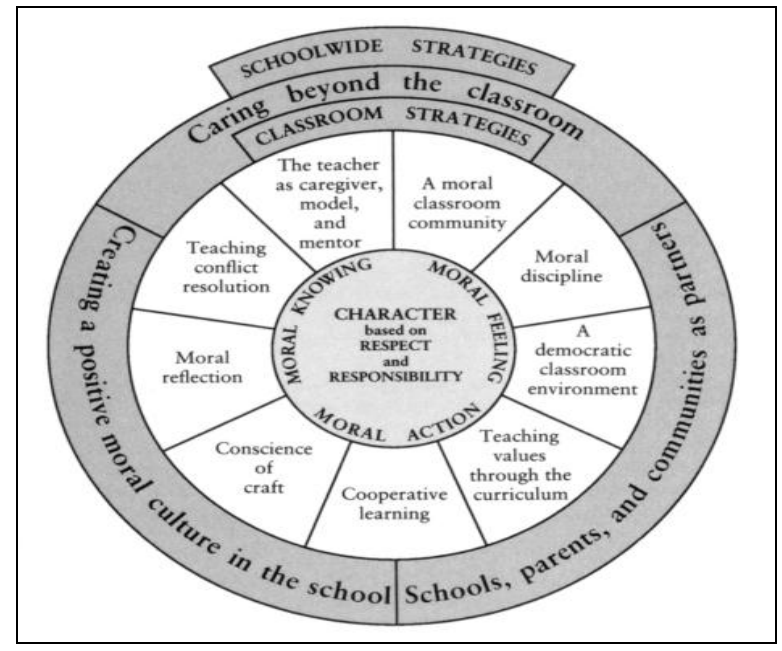

Figure 2. A Comprehensive Approach to Values and Character Education. Reprinted from Educating for character: How our schools can teach respect and responsibility (p. 69) by T. Lickona (1991), New York: Bantam Books

Educating for character in work readiness is an essential program in an educational institution. Again, it is the teacher, lecturer, trainer, or supervisor who plays a major role as caregiver, model and mentor to achieve the main goal of creating in the classroom a moral community of respect and responsibility, so that these qualities become internalized in each student's mind, heart, and hands.

If character is associated with work competence, then it can be grouped into four competencies. The four types of competencies that need to be developed in each individual learner are as follows:

- Core competencies, encompassing a set of values, attitudes, and beliefs that form the cornerstone of the organization's existence, and that every employee or member of the organization needs to possess and perform. For example, the core competence of a customer service employee in a bank is the ability to perform banking operational tasks so as to serve customers with various needs, while the core skills of a journalist are to make and present the news well.

- Competence in human relations, which includes the skills and abilities necessary to interact or connect with others, such as the ability to communicate effectively, the ability to appreciate and tolerate others, especially co-workers, and the ability to participate well in teamwork.

- Technical competence, which encompasses the knowledge and specific skills required for the implementation of certain jobs. For instance, the technical skills of a journalist include being able to find 
and obtain news sources, interview people, record and write the information, and pass it on to audiences of readers or viewers.

- Administrative competence, which includes knowledge and skills for managing and organizing day-to-day tasks in a systematic way.

\section{Method}

The study used a qualitative case study approach. The method provides an opportunity to analyze intensively the process of implementation of education within the learning activities of the students at the Finance and Banking Administration Study Program of the Vocational Education Program at Universitas Indonesia. The data was derived from both primary and secondary sources. Data and information from the primary sources were collected through interviews and observation. Interviews were conducted with lecturers in subjects that were directly involved in educating for character, especially in the field of community programs which served as practical lessons alongside the classroom activities. Interviews were also conducted with students involved in the process or activities of learning. The interviews helped the writer to gather information about the implementation process of the program, and interviewees' personal observations, experience, and opinions helped the writer to understand the challenges and prospects of the process, as well as the content of the education. The author further conducted observation in the field where the learning activities were held. Moreover, valuable data were collected from secondary sources such as organizational records or documents, government regulations, newspapers, books about educating for character, the realities of work and developing work skills, and about the digital era. The collected data were analyzed using a content analysis method.

\section{Discussion}

Vocational education includes higher education in a diploma program and in an applied bachelor's degree program that provides students with specific applied skills for doing a certain job. In vocational education, more emphasis is placed on practical skills through classroom activities, laboratory practices, internship programs, company visits, and other practices to gain work experience. The main role of vocational education is to prepare skilled human resources who are ready to work. Accordingly, in their learning process, students are trained to develop applied skills adapted to a certain field of work, and this can create job opportunities, since he output of the learning process emphasizes work skills to meet industrial or workplace demands. In addition to workoriented skills, vocational education is also oriented toward culture, empowerment, character formation, and personality. Therefore, it is expected that vocational education graduates not only have applied skills, but also have a strong awareness of the surrounding environment.

The 2016 curriculum of the Study Program: Finance and Banking Administration, in the Vocational Program at UI, implemented for the first semester of 2016/2017, is actually an effort to produce workers with character that matches the work situation, that is, the competence of each learner's work. To this end, the 2016 curriculum was developed through extensive discussions with the relevant stakeholders in finance and banking, and by involving lecturers and practitioners, engaging in discussions with practitioners in similar courses, and consulting with professional associations, relevant authority institutions, graduate users, and industries.

As explained earlier, the implementation of this new curriculum integrates three aspects of higher education, or Tridharma, namely: education and teaching; research; and community service. Additionally, all courses offered in the semester are integrated in leading up to a social project in the Community Service Program.

In general, the process of curriculum implementation takes place in two locations, namely, on campus, in the classes where the learning process takes place, with students discussing the conceptual and theoretical aspects of the courses, and from September to December 2016, at the location of the program's place of practice for implementation of community services in a community cooperation, namely, Koperasi Shariah Bhakti Nurul Huda, located in "Depok Permai Housing" at Pancoranmas Subdistrict, Depok, West Java.

The subjects covered in the process of teaching and educating for character building are as follows:

- The Introductory Course of Administration provides conceptual and theoretical knowledge about planning, organizing, cooperating, and achieving organizational goals. This subject educates and trains students in personal skills, interpersonal skills, and group (or organizational) skills, as well as information technology skills, through activities in the community and organization.

- The Pancasila (the Indonesian state ideology that comprises the five basic principles of the state) provides a theoretical concept of attitudes and behaviors that every student should know and apply as a member of Indonesian society. The five principles of Pancasila are

1. Belief in the One and Only God

2. A just and civilized humanity

3. A unified Indonesia nationality 
4. Democracy led by the wisdom of the representatives of the People

5. Social justice for all Indonesians

In this course, the students practice the values of respect and responsibility while doing community services.

- $\quad$ The Applied Statistics course, which provides knowledge and skills in recording, processing, and presenting quantitative and qualitative data in this case study relating to the demographic conditions of the community where the program is held. It is a character skill since it includes knowing how to collect data and information from the locals while exercising good manner and behavior.

- $\quad$ Bahasa Indonesia (Indonesian language) provides the students with theoretical and conceptual knowledge, as well as applied skills concerning written and oral communication techniques, and prepares them to write a report on the community service activities of each group, to be presented orally to an audience of lecturers, financial and banking practitioners, and other students. Each student prepares the report together with their colleagues in the group by using the group skills that have already been discussed and explained in the class sessions.

The New Curriculum 2016 is followed by new students of the 2016 group. The students enroll in a number of courses (described in the previous section) which integrate activities in the classroom with activities in the community. All the courses are pursued by students through a collaborative learning process in the classroom that provides a conceptual and theoretical understanding. Furthermore, guided by lecturers and lecturers' assistants, the students are included in activities with working groups, and then asked to prepare their groups to design a social project to be implemented at the site of community service activities. In short, students then have a conceptual and theoretical knowledge and must apply their skills in work activities.

\section{Establishment of Work Competence -Characters}

In the implementation of this Pengmas or Community Services Program, students are divided into six working groups to gain actual and factual experience in the real world. That is, they have to work at the workplace associated with the organization and the people involved, as well as dealing with the problems faced by organizations that are part of the social project activities which have been designed. Three main topics of this program relate to the fields of economy, education, and health. Each activity program has a target for each group of participants. Table 1 shows the areas of activities and work programs designed and implemented by the students in groups, accompanied by the lecturers in the relevant subjects.

Table 1. Activities in Community Service Program

\begin{tabular}{|l|l|l|}
\hline \multicolumn{1}{|c|}{ Sectors } & \multicolumn{1}{|c|}{ Programs } & \multicolumn{1}{|c|}{ Participants } \\
\hline $\begin{array}{l}\text { Economic } \\
\text { Tuesday, December 20, } \\
\text { 2016 } \\
\text { *Workshop "Accountancy } \\
\text { using Zahir software" } \\
\text { Tuesday 20 December 2016 } \\
* \text { Marketing Strategies }\end{array}$ & $\begin{array}{l}\text { Management of } \\
\text { Bhakti Nurul } \\
\text { Huda } \\
\text { Cooperative; } \\
\text { Locals at the site, } \\
\text { especially } \\
\text { housewives }\end{array}$ \\
\hline $\begin{array}{l}\text { Education } \\
\text { 3. Health }\end{array}$ & $\begin{array}{l}\text { Sunday, December 18, 2016 } \\
\text { Building } \\
* \text { Education fair }\end{array}$ & $\begin{array}{l}\text { Parents and } \\
\text { children Citizens } \\
\text { at Pengmas } \\
\text { location }\end{array}$ \\
& $\begin{array}{l}\text { Monday, December 11, 2016 } \\
\text { 2016 } \\
* \text { Child Nutrition } \\
\text { Counseling }\end{array}$ & $\begin{array}{l}\text { Parents and } \\
\text { children Citizens } \\
\text { at Pengmas } \\
\text { location }\end{array}$ \\
\hline
\end{tabular}

Note: Report on Community Empowerment Program Based on Sharia Cooperatives, Economics, Education, \& Health Depok 2016

Based on direct observation of all programs listed in Table 1, it can be said that the program has been successfully implemented by all involved, especially the students. In this case study, students have applied or exercised their theoretical and conceptual understanding by organizing themselves into working groups. In the working groups, students work with colleagues in their group, and then they plan, organize, implement and control their activities to achieve the program objectives. In accordance with the model in Figure 1, 
(Components of good character), students are trained to cooperate with other people within their group or outside their group (to develop people skills), to find, for example, sources or speakers for their group activities. They practice the ability to organize a small group by establishing organizational structure or dividing task responsibility within the group. Based on the documentation of the activities report, in this case study each group creates its distinctive group organizational structure. For example, there are the positions of Chairperson, Vice Chairperson, Secretary, and Treasurer, as well as various divisions, namely, an Events Division, a Supplies Division, a Public Relations Division, a Publication and Documentation Division, and a Consumer and Field Division. In terms of mastery (of technology), students complete exercises in designing and implementing programs by utilizing computer media technology and other related equipment. Moreover, students are trained to sharpen their skills in core competencies (designing a social project with a program type adapted to local conditions); people competencies (contacting community leaders, involving citizens in programs), technical competencies (preparing technical details of program implementation) and administrative competencies (arranging daily operations to achieve the aims of program implementation).

Before all the programs are implemented, at the beginning of this Pengmas (community services activities), the students are given the task of mapping socio-economic conditions through demographic surveys which will complement the preparation of regional profiles and geographical conditions in the location of the community. In this case study, the Applied Statistics class provides students with the opportunity to go into the field to meet the residents, after obtaining permission from the local Rukun Tetangga or Rukun Warga (the neighborhood leaders). The chairperson of the student group, with the guidance of lecturers and assistant lecturers, has to practice respect and responsible values in relations to others. In this regard, the Pancasila course provides knowledge of the values of Pancasila which are reflected in the selection of program topics that show the concern of citizens about the actual problems in society. Within this integrated activity, lecturers and their assistants act as facilitators. In general, all students can play their assigned roles.

At the end of the activity program, each group of students prepares an Activity Report. This task, in fact, relates to the Indonesian language course. All activities are described in group activity reports (both written and oral presentations). In the Applied Statistics course, each student in each group is given part of the task of collecting data and information about demographic profiles of citizens; thus, this activity can be regarded as a miniature research activity (part of Tri Dharma Perguruan Tinggi). In this activity, Introduction to Administration Sciences becomes the central subject that provides the core competence in the implementation of the Pengmas program.

\section{Results}

The activities described in Section IV provided learning experience that made students/learners more critical, creative, and innovative in facing the tasks or work within the groups. Besides that, students were also prepared to apply the knowledge that had been taught in the classes, in real work activities. Students also had the opportunity to practice cooperative skills in more intensive groups and to work in close contact with the community.

As the first step in this initiative, the new curriculum implementation program within this integrated approach can be considered successful as the program or activities covered three elements, namely, attitude, skills, and knowledge, and the values of respect and responsibility were learned and practiced in the field through the group or team project. In terms of digital technologies, students used computer programs and applications to manage data and information, specifically for searching and processing data, and for writing and presenting each group report. In brief, the whole process encompassed Lickona's components of good character, which include an integrated combination of moral knowing, moral feeling, and moral action, as shown in Figure 1. In fact, moral action, which includes competence, will, and habit, is the main goal. Further, the whole process of engaging in the learning activities can also be seen as synchronized with the elements of learning achievement in the Indonesian National Qualification Framework (KKNI), which includes three major features for building students' character for work readiness, specifically in the digital era, as shown in Table 2.

Table 2 The Elements of Learning Achievement in KKNI

\begin{tabular}{|c|c|c|}
\hline & 1. Skills (work abilities) & *Trained in work ethics \\
$\mathbf{P}$ & & *Understands globalization \\
$\mathbf{A}$ & & *Flexible in work choice \\
\cline { 2 - 3 } $\mathbf{R}$ & 2. Knowledge (knowledge) & *Analysis, synthesis, creation \\
$\mathbf{A}$ & & *IT Knowledge \\
$\mathbf{M}$ & & *Communication \\
$\mathbf{E}$ & & *Foreign language \\
$\mathbf{T}$ & 3. Attitude (people skills) & *Leadership \\
$\mathbf{E}$ & & *Cooperative (teamwork) \\
$\mathbf{R}$ & & *Work in a group \\
\hline \multicolumn{3}{|c|}{ *Moral Knowing-Moral Feeling-Moral Action } \\
\hline
\end{tabular}


Note: From Manajemen Pendidikan Teknologi Kejuruan dan Vokasi (2017), by B. Wibawa, Jakarta: Bumi Aksara. Adapted into English and expanded in relation to the components of good character (Moral knowing, moral feeling, and moral action) described in Educating for character: How our schools can teach respect and responsibility by T. Lickona (1991), New York: Bantam Books.

The program provides experience of the process of educating for a character of work readiness by conducting education and learning in the classroom as well as in the real world (the community). Therefore, it includes the theories and applied skills, as well as experience, which promote the core values of respect and responsibility in this current era. Students demonstrate their actual skills in working or dealing with other people, both within the groups and outside the groups, and use computer applications to write and present reports. They apply their knowledge to read, analyze, and present data in their reports, and demonstrate their attitude in relation to people skills, leadership, cooperative teamwork, and work ethics. As this is the first experience of this process, there is opportunity for the program to be developed for better results in the future. A suggestion with regard to educating for character is the formation of groups assigned to maintain the sustainability of the programs that have been implemented previously. Teams of lecturers need to conduct continuous monitoring and evaluation of indicators of the successful implementation of the program, and thus develop an assessment of the effectiveness of the education process and content. Lecturers and their teams need to develop procedures to monitor and evaluate changes in learners' personality aspects in terms of attitude, character, personality, and behavior.

\section{Conclusions}

Educating for character in work readiness can be concluded successfully if executed properly. It can be achieved by establishing work competence through a program that integrates three aspects of colleges' Tridharma, namely, education and teaching, research and development, and dedication to the community. The success of the enterprise is shown by the success of all student groups in planning, organizing, executing, and reporting their activities. The students also practiced the values of respect and responsibility, which blended with the core competence of the study programs, as well as using digital technologies and software. Moreover, local residents also responded to the students' programs in a highly participative way. These programs can be considered highly innovative, providing an alternative solution to actual social problems in the three areas of economics, education, and health. With this activity, the students' work competence is developed and formed to make them effectively work-ready.

\section{References}

Crawford, R. (1991). In the era of human capital: the emergence of talent, intelligence, and knowledge as the worldwide economic force and what it means to managers and investors. New York: Harper Collins.

Houle, D. (2012). Entering the shift age: The end of the information age and the new era of transformation. Naperville: Sourcebooks

Direktorat Jenderal Kelembagaan Iptek dan Dikti

Kementerian Riset, Teknologi dan Pendidikan Tinggi. (2016). Revitalisasi Pendidikan Tinggi Vokasi Menerapkan Sistem $3+2+1$. May 14, 2017. Retrieved from http://kelembagaan.ristekdikti.go.id/index.php/2016/10/31/revitalisasipendidikan-vokasi-menerapkan-sistem-321/

Kementrian Riset Teknologi dan Pendidikan Tinggi Republik Indonesia (2017) Menghadapi Urgensi Pendidikan Vokasi. Retrieved from http://www.dikti.go.id/menghadapi-urgensi-pendidikan-vokasi/

Lickona, T. (1991). Educating for character: How our schools can teach respect and responsibility. New York: Bantam Books

Kementrian Riset Teknologi dan Pendidikan Tinggi Republik Indonesia. (2017). Tantangan dan Arah Perkembangan

Soemarno, R.M. (2018). Peran Serta BUMN dalam Meningkatkan Kualitas Pendidikan Vokasi. Orasi Ilmiah pada Dies Natalis ke-10 Program Pendidikan Vokasi, Universitas Indonesia. Depok: UI

Shepherd, J. (2004). What is the Digital Era?. In G. Doukidis, N. Mylonopoulos, \& N. Pouloudi (Eds.), Social and Economic Transformation in the Digital Era (pp. 1-18). Hershey, PA: IGI Global. doi:10.4018/978-1-59140-158-2.ch001

Widarto. (n. d.). Model Pendidikan Vokasi yang Efektif dan Efisien, 1-31.

Whetten, D.A. \& Cameron, K.S. (1995). Developing management skills. New York: Harper Collins

Wibawa, B. (2017). Manajemen Pendidikan Teknologi Kejuruan dan Vokasi. Jakarta: Bumi Aksara 